\title{
Sinus floor augmentation using a mineralized freeze-dried bone graft combined with recombinant human bone morphogenetic protein-2: clinical and histological results of three cases
}

\author{
Ock-Hyun Cho ${ }^{1}$, Won-Pyo Lee², and Sang-Joun Yü* \\ ${ }^{1}$ Resident, Department of Periodontology, School of Dentistry, Chosun University, Gwangju, Republic of Korea \\ ${ }^{2}$ Assistant Professor, Department of Periodontology, School of Dentistry, Chosun University, Gwangju, Republic of Korea \\ ${ }^{3}$ Professor, Department of Periodontology, School of Dentistry, Chosun University, Gwangju, Republic of Korea
}

The purpose of this study was to evaluate clinical and histological outcomes using a freeze-dried bone allograft (FDBA) combined with recombinant human bone morphogenetic protein-2 (rhBMP-2) in sinus floor augmentation. Sinus floor augmentation was performed in three patients using the FDBA and rhBMP-2. After a 5-month healing period, biopsies were performed simultaneously with implant surgery. It was possible to obtain enough bone to place implants quantitatively and to obtain excellent initial fixation of implants qualitatively. In this case series, the results showed that rhBMP-2 encourages bone formation and enough bone can be made to place implants when performing sinus floor augmentation with FDBA.

Key Words: Allograft; Bone morphogenetic protein 2; Sinus floor augmentation

(c) This is an open-access article distributed under the terms of the Creative Commons Attribution Non-Commercial License (http://creativecommons.org/licenses/by-nc/4.0) which permits unrestricted noncommercial use, distribution, and reproduction in any medium, provided the original work is properly cited.

\section{Introduction}

임플란트는 무치악 부위에서 상실된 치아를 대체할 수 있는 최선의 방법으로 고려되고 있다. 이러한 임플란트를 식립하기 위해선 충분한 수평적, 수직적 골량이 필요하다. 임플란트를 식 립하기에 치조골이 부족한 경우 상악동 거상술, 골유도 재생술 (guided bone regeneration, GBR) 등의 치조골 이식술이 필요 하다. 사용되는 골이식재로는 자가골, 동종골, 이종골, 합성골 등이 있다. 이중 자가골은 골형성(osteogenesis), 골유도(osteoinduction), 골전도(osteoconduction)의 성질을 모두 가지고 있는 특성 및 면역반응을 유발하지 않는 특성 때문에 우선적으 로 고려될 수 있지만 충분한 양을 채득하기가 힘들고 수술 부위
가 늘어나고 이식 후 흡수가 많이 발생하는 단점이 있다[1]. 따 라서 이에 대한 대안으로 동종골, 이종골, 합성골 이식재들이 활 발히 연구되어 실험 및 임상에 적용되고 있다. 동종골의 경우 탈 회동종골(demineralized freeze-dried bone graft, DFDBA)과 비탈회동종골(mineralized freeze-dried bone graft, FDBA)로 나뉘는데 탈회동종골의 경우 골유도성, 골전도성이 있으나 비 탈회동종골의 경우 골유도성은 결여 되어 있다고 보고되고 있 다. 이종골과 합성골의 경우에도 골형성능, 골유도능이 결여되 어 있어 골전도성만으로 골조직 재생을 증진시킨다[2].

골유도는 결손부 내에 존재하는 또는 주위의 혈행에서 유래 한 골전구세포들을 골모세포로의 분화로 유도하여 골모세포를 통한 신생골 형성을 촉진함으로써 새로운 골을 형성하는 것을

Received October 18, 2021; Revised October 27, 2021; Accepted October 29, 2021

*Corresponding author: Sang-Joun Yu, Department of Periodontology, School of Dentistry, Chosun University, 309 Pilmun-daero, Dong-gu, Gwangju 61452, Republic of Korea.

Tel: +82-62-220-3850, Fax: +82-62-224-4664, E-mail: sjyu78@chosun.ac.kr 
말한다. 골유도는 골형성 세포의 활성화를 유도하는 중간 매개 체에 의해서 이루어지는데 골형성유도단백질(bone morphogenetic protein, BMP)이 골전구세포의 골모세포로의 분화를 유도한다고 보고되면서 골재생을 촉진하는 매개체로서 가장 많 은 연구가 이루어지고 있다[3,4].

치과분야에서 BMP 관련 연구들은 주로 임플란트 주위 치조 골 형성을 위한 골유도재생술, 상악동거상술에서 비계(scaffold)와 결합된 형태로 BMP가 적용된 경우였으며, 이 연구들은 골전도성만 보유한 골이식재에 $\mathrm{BMP}$ 을 통해 골유도성을 부여하 고 골재생능력을 평가하기 위함이었다[3]. 특히 이중에 BMP-2 는 체내에서 성장 및 분화인자로 작용하며, 간엽 줄기세포-골 전구세포(osteoprogenitor)-조골모세포(preosteoblast)-골모 세포(osteoblast)-골화골모세포(osteocytic osteoblast)-골세포 (osteocyte)에 이르는 골형성 전체 단계에서 광범위하게 작용 하여 신생골의 생성을 촉진하는 것으로 알려져 있다[4]. 여러 골 이식재들 중에 지금까지 상악동거상술에서 해면골(cancellous bone)과 피질골(cortical bone)을 3:7의 비율로 혼합한 비탈회 동종골(mixed $\mathrm{FDBA}$ )을 $\mathrm{BMP}-2$ 와 함께 혼합하여 골재생능력을 평가한 연구는 보고되지 않았다.

이 연구에서는 재조합 사람 유래 골형성유도단백질(recombinant human bone morphogenetic protein-2, rhBMP-2)를 mixed FDBA와 섞어 GBR과 상악동 거상술에 적용한 후 임상 결과와 조직학적 분석을 통한 증례보고를 하고자 한다. 상기 연 구는 조선대학교 치과병원 생명윤리심의위원회 승인을 받은 후 시행되었다(IRB no. CUDHIRB 2020007).

\section{Case Description}

\section{Case 1}

57세 남성 환자로 \#26 치아부위의 잇몸이 부었다는 주소로 내원하였다. 예방적으로 아스피린 복용 중이었으며 특이 할만 한 전신질환은 없었다(Table 1). 치은부종이 관찰되어 당일 국 소마취(lidocaine 2\%, epinephrine 1:100,000; Yuhan, Seoul, Korea) 하에 치근활택술을 시행하였으며 일주일 뒤 내원 시 파
노라마 사진상에서 치근단 병소 관찰되고 치은부종 지속 및 electric pulp test (EPT)(-) 관찰되어 보존과로 의뢰되었다. 보 존과에서 근관치료 후 통증은 감소하였으나 심한 동요로 인해 보존 불가할 것으로 판단되어 치주과로 재의뢰되어 발거 후 임 플란트 식립 계획되었다.

발치 3개월 후 촬영된 컴퓨터 단층 촬영(cone beam computed tomography, CBCT) 방사선 사진상에서 남은 잔존치 조골의 수직적 높이가 $0.95 \mathrm{~mm}$ 로 관찰되었다. 따라서 임플란 트 식립을 위한 충분한 골을 확보하기 위해서 mixed FDBA와 $\mathrm{rhBMP}-2$ 를 사용한 상악동저골이식술과 잔존 치조골의 치관측 으로 mixed FDBA와 흡수성 차폐막을 사용한 골유도재생술을 시행하기로 계획되었다.

국소 마취하에 치조정 절개 및 \#25 치아의 원심측에 수직절 개를 시행한 후 골막기자를 사용하여 전층판막을 거상하였다. $\mathrm{CBCT}$ 상에서 관찰된 치관측의 부족한 잔존 치조골을 확인할 수 있었다. 전층 판막이 거상된 수술부위에 piezosurgery (MEC$\mathrm{TRON}$, Carasco, Italy)을 사용하여 상악동 측방골에 골창을 형 성한 후 상악동막을 거상하였다. Mixed FDBA (Do bone; Renew medical, Bucheon, Korea) 2 cc와 rh-BMP2 (NovosisDent; CGBIO, Seoul, Korea)를 혼합하여 거상된 상악동저에 충전하고 치조제 치관측으로도 골이식술 시행하였다. 상방으 로 Bone tack (Osung, Gimpo, Korea)을 사용하여 흡수성 차폐 막인 collagen membrane (GENOSS, Suwon, Korea)을 고정 하여 폐쇄하였다. 비흡수성 봉합사(Happylon; Shirakawa Co., Takayama, Japan)를 이용하여 봉합을 시행하고 술후 파노라마 방사선사진과 $\mathrm{CBCT}$ 를 촬영하였다. 술 전 $\mathrm{CBCT}$ 사진과 비교했 을 때, 치조제 높이가 $0.95 \mathrm{~mm}$ 에서 수술직후 $14.69 \mathrm{~mm}$ 로 충 전된 골이식재로 인해서 증가된 모습을 관찰할 수 있었다(Fig. 1).

상악동저 골이식술 및 골유도재생술 5개월 뒤에 임플란트 술 전 $\mathrm{CBCT}$ 촬영 후 이식재가 일부 수축하였으나 표준형 임플란 트를 식립하기에 충분한 높이 $11.32 \mathrm{~mm}$ 의 치조골을 확보할 수 있었다.

국소마취 하에 치조정절개 및 \#25 치아의 원심측에 수직절 개를 시행하여 전층판막을 거상하였다. \#26 부위의 상악동거 상 부위의 초기 드릴을 이용하여 상악동하연까지 삭제한 후

Table 1. Case summary

\begin{tabular}{ccllcccc}
\hline Case no. & Age $(\mathbf{y})$ & Gender & Site & Implant system $(\mathbf{D} \times \mathbf{L})$ & ISQ $(\mathbf{B} / \mathbf{P})$ & $\mathbf{R B H}$ & $\mathbf{A B H}$ \\
\hline 1 & 57 & Man & $\# 26$ & $4.5 \times 12$ & $75 / 72$ & $0.95 \mathrm{~mm}$ & $11.32 \mathrm{~mm}$ \\
2 & 75 & Woman & $\# 15$ & $3.5 \times 11.5$ & $80 / 81$ & $1.81 \mathrm{~mm}$ & $18.02 \mathrm{~mm}$ \\
3 & 60 & Woman & $\# 25$ & $4.5 \times 12$ & $75 / 76$ & $1.86 \mathrm{~mm}$ & $18.00 \mathrm{~mm}$ \\
\hline
\end{tabular}

$\mathrm{D}$, diameter of implant (mm); L, length of implant (mm); ISQ, implant stability quotient; B, buccal direction; P, palatal direction; RBH, residual bone height before the surgery; $\mathrm{ABH}$, augmented bone height after bone healing. 

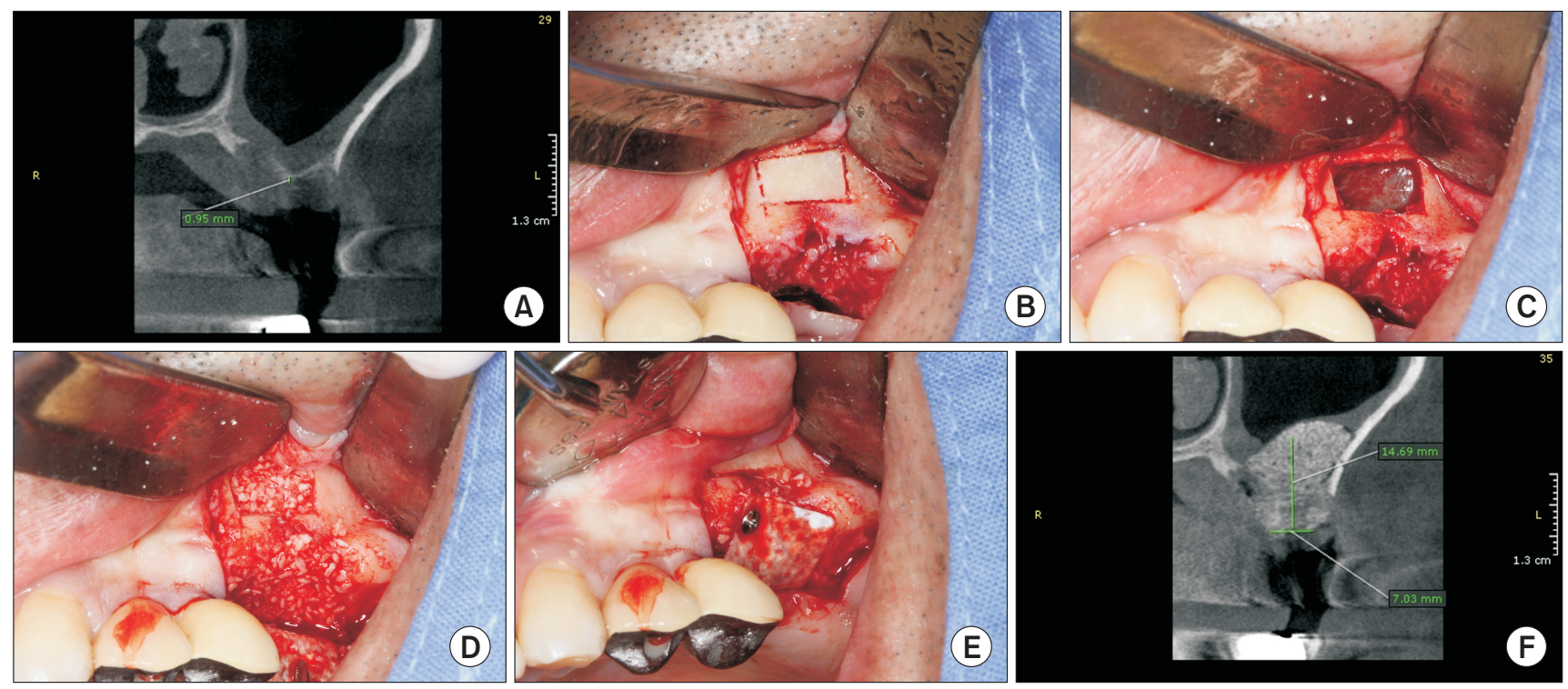

Fig. 1. Cone-beam computed tomography (CT) images and surgical procedure of case 1. (A) CT view before sinus floor elevation. (B) After fullthickness flap was elevated, a lateral window access was formed using a piezoelectric device. (C) The lateral window was removed. (D) The mixed FDBA and rhBMP2 were placed into the sinus floor space after elevation of the sinus membrane and bone grafting was performed on the crestal defect of the residual alveolar ridge. (E) The collagen membrane was placed and fixed by the Bone tack (Osung, Gimpo, Korea). (F) CT view after the surgery. FDBA, freeze-dried bone allograft; rhBMP-2, recombinant human bone morphogenetic protein-2.

trephine bur를 이용하여 임플란트 식립 전 상악동 내의 골조 직을 채취하였고 생검 샘플은 직경 $2 \mathrm{~mm}$, 길이 $8 \mathrm{~mm}$ 크기였 다. \#26 부위에 직경 $4.5 \mathrm{~mm}$, 길이 $12 \mathrm{~mm}$ 의 임플란트를 제조 사의 지시대로 식립하였다. ISQ (Osstell Mentor; Osstell Co., Stampgatan, Sweden) 수치를 측정하였고 그 수치는 협측방향 으로 75 , 구개측방향으로 72 로 측정되어 양호한 초기 고정력 을 관찰할 수 있었다. 4 개월 후에 2차 수술을 통해 치유 지대주 (healing abutment)를 체결하고 비흡수성 봉합사를 이용하여 일차봉합을 시행하였다(Fig. 2).

조직학적인 평가를 위해 채취된 골시편을 $4 \%$ 완충 포르말린 으로 2일간 고정하고, $10 \%$ formic acid로 2주간 탈회하였다. 파라핀에 포매한 후 $7 \mu \mathrm{m}$ 두께로 절단하였다. 이를 Hematoxylin-Eosin 으로 염색한 후 광학현미경(Leica DM750; Leica Microsystems Ltd., Heerbrugg, Switzerland) 으로 관찰하였 다. 조직계측학적 평가는 i-Solution software (IMT i-Solution Inc., Burnaby, BC, Canada)을 이용하여 시행하였다.

조직학적으로 이식된 골이식재들 주위로 신생골 침착이 활발 하게 진행되었고, 이식재와 신생골간의 완전한 유합이 관찰되 었다. 골조직 사이를 채우고 있는 소성 섬유성 결체조직 내에서 미약한 만성염증세포의 침윤이 관찰되나 특기할 염증 및 이물 반응 소견은 관찰되지 않았다.

조직형태계측학적으로 잔존골이식재, 신생골조직, 그리고 소 성 섬유성결체조직의 구성은 잔존골이식재 $10.3 \%$, 신생골조직
$41.2 \%$, 소성 섬유성결체조직 48.5\%였다(Fig. 3).

\section{Case 2}

75세 여성환자로 \#14-15 unit bridge가 많이 흔들린다는 주 소로 내원하였다. 당뇨, 고혈압, 관절약을 복용 중이었다(Table 1). 초진 파노라마 방사선 사진에서 \#14-15 bridge의 지대치에 치조골 소실 및 치근단 침범이 관찰되어 발치한 후 임플란트를 식립할 것을 계획하였다.

발치 3 개월 후에 촬영한 $\mathrm{CBCT}$ 상에서 남은 잔존 치조골의 수 직적 높이가 $2 \mathrm{~mm}$ 이내로 관찰되었다. 따라서 임플란트 식립을 위한 충분한 골을 확보하기 위해서 rhBMP-2와 mixed FDBA을 이용하여 상악동저골이식술을 시행하고 치조골의 치관측으로 골이식재와 흡수성 차폐막을 사용한 골유도재생술을 시행하기 로 계획하였다.

국소 마취 하에 치조정 절개 및 견치 근심측에 수직절개를 시 행하여 전층판막으로 거상하였다. 임플란트를 식립할 부위에서 부족한 잔존 치조골을 확인할 수 있었다. 골막기자를 사용하여 전층 판막을 거상하고 piezosurgery를 사용하여 상악동의 측방 으로 접근하는 골창을 만들고 상악동막을 거상하였다. Mixed FDBA 4 cc와 rhBMP-2를 혼합하여 거상된 상악동저에 충전하 고 치조제의 치관측으로 골이식술 시행하였다. 치근단 부위와 치조제 상방에 Bone tack을 사용하여 흡수성 차폐막인 Osseo- 

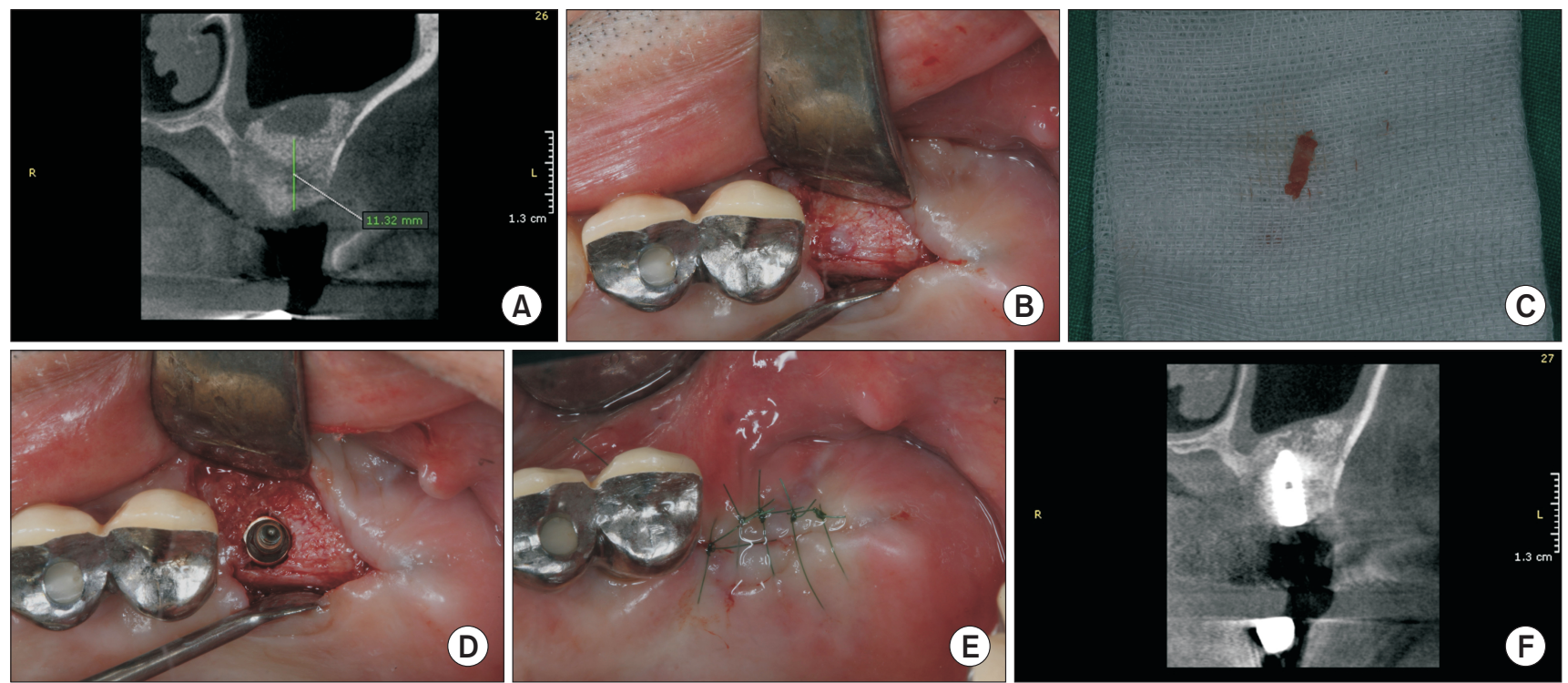

Fig. 2. Cone-beam computed tomography (CT) images and surgical procedure after bone healing of case 1. (A) CT view after 6 months of bone healing. (B) After full-thickness flap was elevated, the newly formed alveolar ridge was observed. (C) Core biopsies were harvested using a trephine bur (inner diameter $2 \mathrm{~mm}$ ). (D) After the alveolar bone was drilled, the implant fixture was placed. (E) The primary closure was performed with mono-filament suture. (F) CT view after the insertion of the implant.
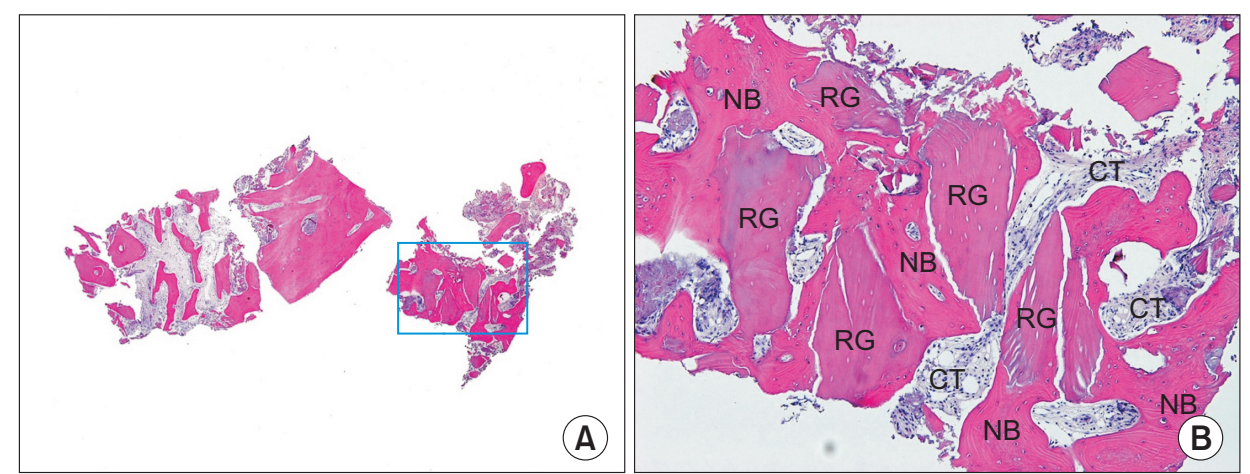

Fig. 3. Histologic view and histomorphometric analysis of case 1 (H\&E stained, A: $\times 40, B: \times 100)$. (A) The newly formed bone is actively deposited around the transplanted bone grafts, and complete fusion between the graft and the new bone is achieved. The gaps between the trabeculae of bone are filled with loose CT. (B) The sample shows $41.2 \%$ NB, 10.3\% RG, and 48.5\% CT. NB, newly formed bone; RG, residual bone graft; CT, connective tissue.

guard (ZIMMER BIOMET, Warsaw, Sweden)을 고정하고 폐쇄 하였다. 비흡수성 봉합사를 이용하여 봉합을 시행하고 술후 파 노라마 방사선사진과 $\mathrm{CBCT}$ 를 촬영하였다. 술전 $\mathrm{CBCT}$ 사진과 비교하여, 잔존 치조제 높이가 $1.81 \mathrm{~mm}$ 에서 수술직후 15.16 $\mathrm{mm}$ 으로 증가된 모습을 관찰할 수 있었다(Fig. 4).

상악동저 골이식술 및 골유도재생술 후 5개월 뒤에 임플란트 술전 $\mathrm{CBCT}$ 촬영 결과 표준형 임플란트를 식립에 충분한 높이인 $18.02 \mathrm{~mm}$ 의 치조골을 확보할 수 있었다.

임플란트를 식립하기 위해서 국소마취하에 치조정절개 및 \#13 치아의 원심측에 수직절개를 시행하여 전층판막을 거상하
였다. 그 후 \#15 부위 치조정에서 trephine bur를 이용하여 골 조직 채취을 채취하였고, 샘플은 직경 $2 \mathrm{~mm}$, 길이 $6 \mathrm{~mm}$ 크기 였다.

\#14 부위에 직경 $3.5 \mathrm{~mm}$, 길이 $11.5 \mathrm{~mm}, \# 15$ 부위에 직경 $4.0 \mathrm{~mm}$, 길이 $11.5 \mathrm{~mm}$ 의 임플란트를 제조사의 지시대로 식립 하였다. ISQ 수치는 \#14의 임플란트에서 협측방향으로 76, 구 개측 방향으로 $78, \# 15$ 의 임플란트에서는 협측방향으로 80 , 구 개측 81이 측정되어 양호한 초기 고정력이 관찰할 수 있었다. 4 개월 후 2차 수술을 통해 치유 지대주를 체결하고 비흡수성 봉 합사를 이용하여 봉합을 시행하였다(Fig. 5). 

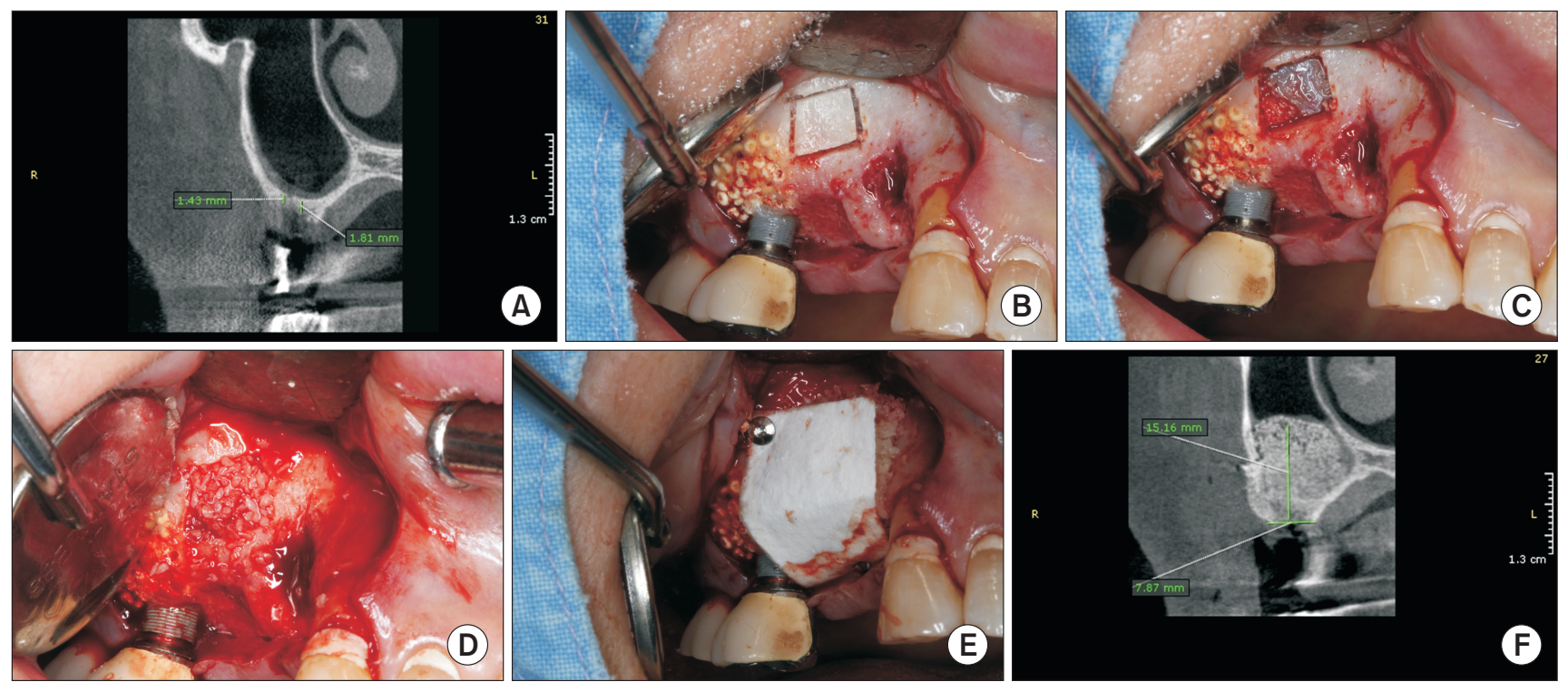

Fig. 4. Cone-beam computed tomography (CT) images and surgical procedure of case 2. (A) CT view before sinus floor elevation. (B) After fullthickness flap was elevated, a lateral window access was formed using a piezoelectric device. (C) The lateral window was removed. The grafted alveolar ridge around \#16 area was observed beside the surgical site. (D) The mixed FDBA and rhBMP2 were placed into the sinus floor space after elevation of the sinus membrane. (E) The bone grafting was performed on the crestal defect of the residual alveolar ridge and the collagen membrane was placed and fixed by the Bone tack (Osung, Gimpo, Korea). (F) CT view after the surgery. FDBA, freeze-dried bone allograft; rhBMP-2, recombinant human bone morphogenetic protein-2.
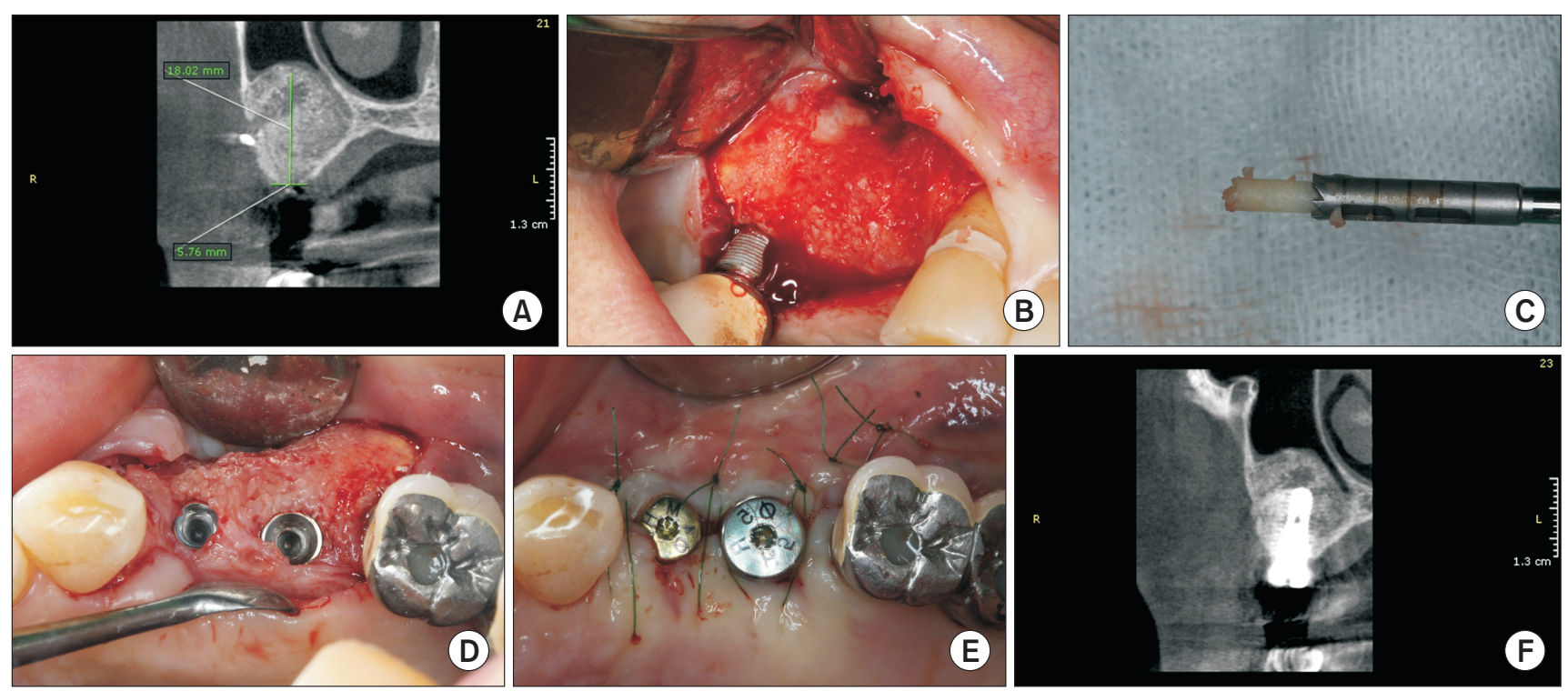

Fig. 5. Cone-beam computed tomography (CT) images and surgical procedure after bone healing of case 2. (A) CT view after 6 months of bone healing. (B) After full-thickness flap was elevated, the newly formed alveolar ridge was observed. (C) Core biopsies were harvested using a trephine bur (inner diameter $2 \mathrm{~mm}$ ). (D) After the alveolar bone was drilled, the implant fixtures were placed. (E) The healing abutments were applied and the primary closure was performed. (F) CT view after the insertion of the implants.

조직학적인 평가를 위해 채취된 골시편을 $4 \%$ 완충 포르말린 으로 2일간 고정하고, $10 \%$ formic acid로 2주간 탈회하였다. 파 라핀에 포매한 후 $7 \mu \mathrm{m}$ 두께로 절단하였다. 이를 Hematoxy-
lin-Eosin으로 염색한 후 광학현미경으로 관찰하였다. 조직계측 학적 평가는 i-Solution software을 이용하여 시행하였다.

조직학적으로 이식된 골이식재들 주위로 활발한 신생골의 형 


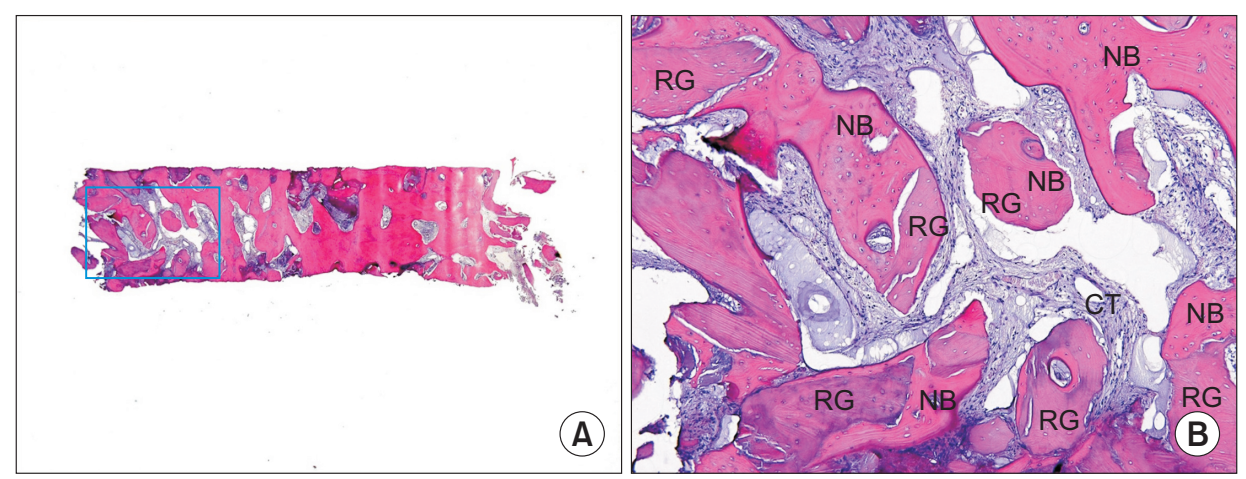

Fig. 6. Histologic view and histomorphometric analysis of case 2 (H\&E stained, A: $\times 40, \mathrm{~B}: \times 100)$. (A) The active formation of new bone around the grafted bone graft is observed, a number of grafts are buried in the newly formed bone matrix. Overall bone density is good. The gaps between the trabeculae of bone is filled with loose CT. (B) The sample shows 55.0\% NB, 11.7\% RG, and 33.3\% CT. NB, newly formed bone; RG, residual bone graft; CT, connective tissue.

성으로 다수의 이식재들이 새롭게 형성된 골기질내에 매몰되어 관찰되었다. 전반적인 골밀도도 양호하며, 골조직 사이사이를 채우고 있는 소성결체 조직내에서 미약한 만성 염증세포의 침윤 이 관찰되나 특기할 염증 및 이물반응 소견은 관찰되지 않았다.

조직형태 계측학적으로 잔존골이식재, 신생골조직, 그리고 소성 섬유성 결체조직의 구성은 잔존골이식재 $11.7 \%$, 신생골조 직 55.0\%, 소성 섬유성결체조직 33.3\%였다(Fig. 6).

\section{Case 3}

60세 여성환자로 기존 상악 RPD 사용중이었으나 불편감을 이유로 임플란트 상담 차 내원하였다. 전신질환이나 복용 중인 약물은 없었다(Table 1). 잔존치아들 중에서 \#24 치아는 예후가 불량하여 발치한 후 \#24-26부위에 임플란트를 식립할 것을 계 획하였다.

발치 2개월 후 측방 접근법을 이용한 상악동저 골이식술을 시 행하였다. 국소 마취하에 치조정 절개 및 \#23 치아의 원심측에 수직절개를 시행하여 전층판막으로 거상하였다. 치관측의 부 족한 잔존 치조골을 확인할 수 있었다. 골막기자를 사용하여 전 층 판막을 거상한 후 piezosurgery를 사용하여 측방으로 접근하 는 골창을 만든 후 상악동막을 거상하였다. Mixed FDBA 4 CC 와 rhBMP-2를 혼합하여 거상된 상악동저에 충전하고 치조제의 치관측으로 골이식술 시행하였다.

치조정, 근심협측, 원심협측에 Bone tack을 사용하여 흡수 성 차폐막인 Osseoguard을 고정하고 폐쇄하였다. 비흡수성 봉 합사를 이용하여 봉합을 시행하고 술후 파노라마 방사선사진과 $\mathrm{CBCT}$ 를 촬영하였다. 술전 $\mathrm{CBCT}$ 사진과 비교했을 때, 수술직후 잔존 치조골의 높이가 $1.86 \mathrm{~mm}$ 에서 $18 \mathrm{~mm}$ 로 증가된 모습을 관찰할 수 있었다(Fig. 7).
상악동저 골이식술 및 골유도재생술 후 5개월 후에 임플란트 식립 전에 $\mathrm{CBCT}$ 를 촬영한 결과, 표준형 임플란트를 식립하기에 충분한 높이인 $18 \mathrm{~mm}$ 의 치조골을 관찰할 수 있었다.

국소마취하에 치조정절개 및 \#23 치아의 원심측에 수직절 개를 시행하여 전층판막을 거상하였다. \#25, 26 부위에서 trephine bur를 이용하여 골조직을 채취하였고 채취된 조직은 직 경 $2 \mathrm{~mm}$, 길이 $6 \mathrm{~mm}$ 크기였다.

\#24 부위에 직경 $4.0 \mathrm{~mm}$, 길이 $12 \mathrm{~mm}$, \#25 부위에 직경 4.5 $\mathrm{mm}$, 길이 $12 \mathrm{~mm}$, \#26 부위에 직경 $4.5 \mathrm{~mm}$, 길이 $12 \mathrm{~mm}$ 의 임플란트를 제조사의 지시대로 식립하였다. ISQ 수치는 \#24의 임플란트에서 협측방향으로 77, 구개측방향으로 77, \#25의 임 플란트에서 협측방향으로 75 , 구개측방향으로 $76, \# 26$ 의 임플 란트에서 협측방향으로 75 , 구개측방향으로 74 가 측정되어 양 호한 초기 고정력을 관찰할 수 있었다. 4개월 후 2차 수술 시에 치유 지대주를 체결하고 비흡수성 봉합사를 이용하여 봉합을 시행하였다(Fig. 8).

조직학적인 평가를 위해 채취된 골시편을 $4 \%$ 완충 포르말린 으로 2 일간 고정하고, $10 \%$ formic acid로 2주간 탈회하였다. 파 라핀에 포매한 후 $7 \mu \mathrm{m}$ 두께로 절단하였다. 이를 Hematoxylin-Eosin으로 염색한 후 광학현미경으로 관찰하였다. 조직계측 학적 평가는 i-Solution software를 이용하여 시행하였다.

조직학적 평가에서 일부 이식된 골이식재들 주위로 신생골의 침착으로 서로 유합되기도 하나 이식재들이 조밀하게 분포된 영역에서는 일부 이식재들과 주위 섬유성 결체조직의 변성소견 이 관찰되었다. 그러나 미약한 만성 염증세포의 침윤이 관찰될 뿐 특기할 염증 및 이물 반응 소견은 관찰되지 않았다.

조직형태계측학적으로 잔존골이식재, 신생조직, 그리고 소 성 섬유성결체조직의 구성은 잔존골이식재 $16.1 \%$, 신생골조직 20.1\%, 소성 섬유성결체조직 $63.8 \%$ 였다(Fig. 9). 

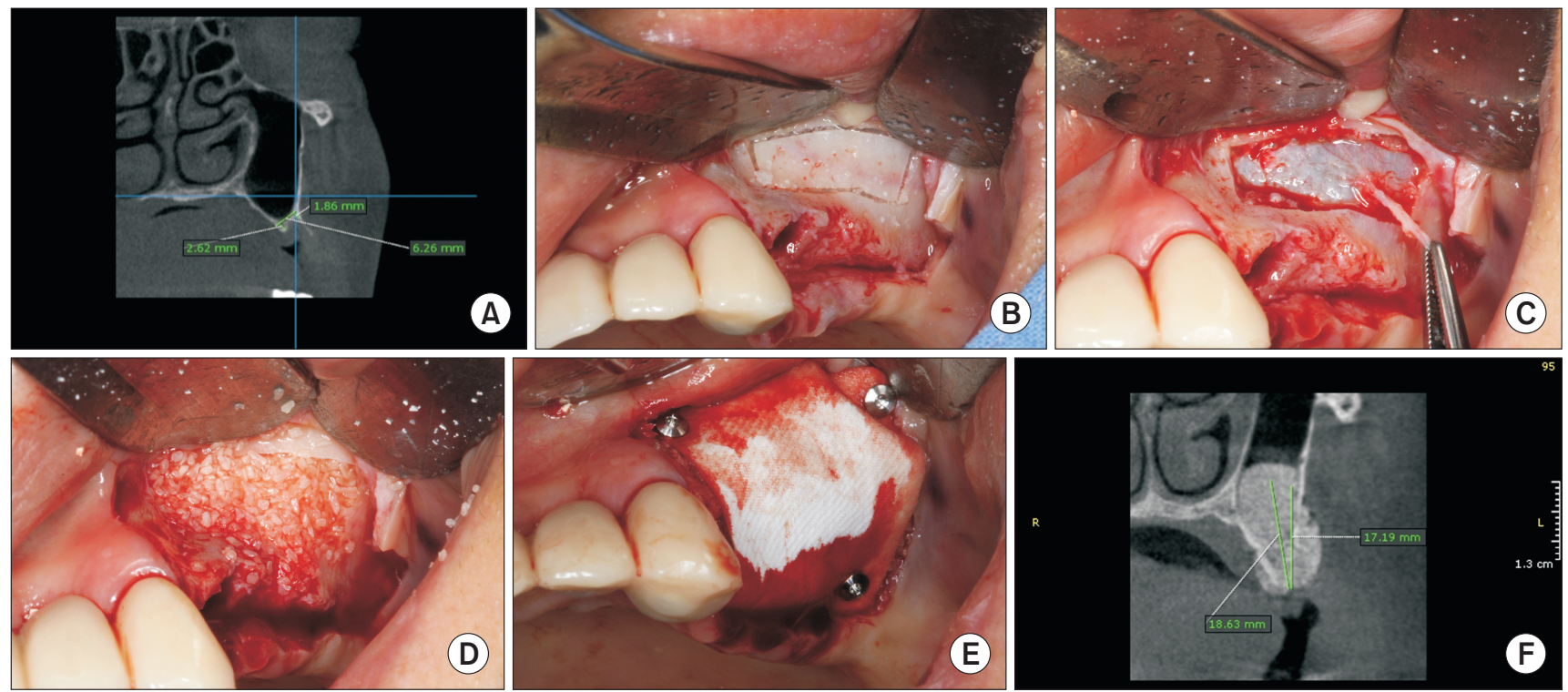

Fig. 7. Cone-beam computed tomography (CT) images and surgical procedure of case 3. (A) CT view before sinus floor elevation. (B) After fullthickness flap was elevated, a lateral window access was formed using a piezoelectric device. (C) The lateral window was removed. The vessel was observed on the sinus membrane. (D) The mixed FDBA and rhBMP2 were placed into the sinus floor space after elevation of the sinus membrane and the bone grafting was performed on the crestal defect of the residual alveolar ridge. (E)The collagen membrane was placed and fixed by the Bone tack (Osung, Gimpo, Korea). (F) CT view after the surgery. FDBA, freeze-dried bone allograft; rhBMP-2, recombinant human bone morphogenetic protein-2.
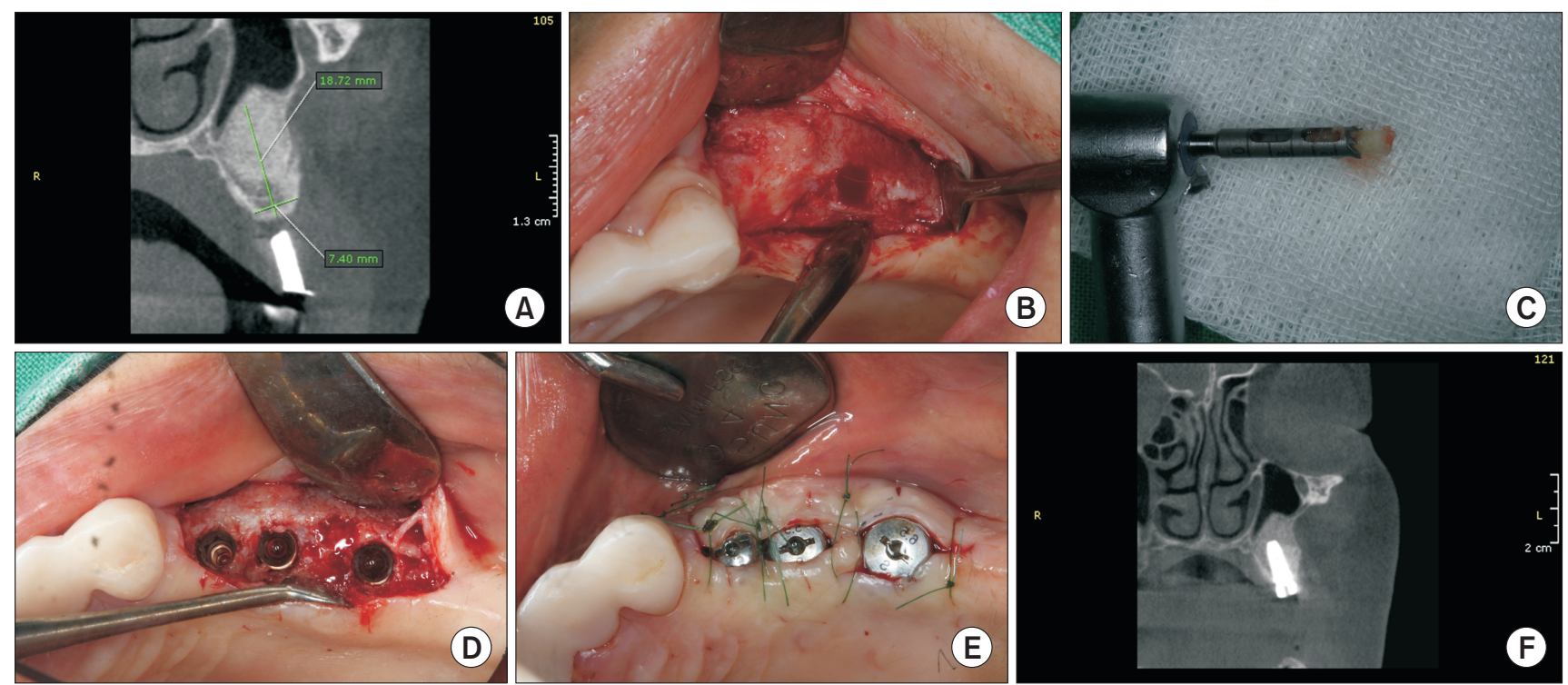

Fig. 8. Cone-beam computed tomography (CT) images and surgical procedure after bone healing of case 3. (A) CT view after 6 months of bone healing. (B) After full-thickness flap was elevated, the newly formed alveolar ridge was observed. (C) Core biopsies were harvested using a trephine bur (inner diameter $2 \mathrm{~mm}$ ). (D) After the alveolar bone was drilled, the implant fixtures were placed. (E) The healing abutments were applied and the primary closure was performed. (F) CT view after the insertion of the implants.

\section{Discussion}

$\mathrm{BMP}$ 는 인체에서 발견되는 자연적으로 형성된 다기능 성장
인자의 그룹이며 형질 전환 성장 인자 $\beta$ (TGF- $\beta$ )의 중의 일부 이다. BMP는 세포 내 단백질의 신호전달 경로를 인산화하고 활 성화시키는 특정 세린-쓰레오닌 키나아제(serine-threonine 


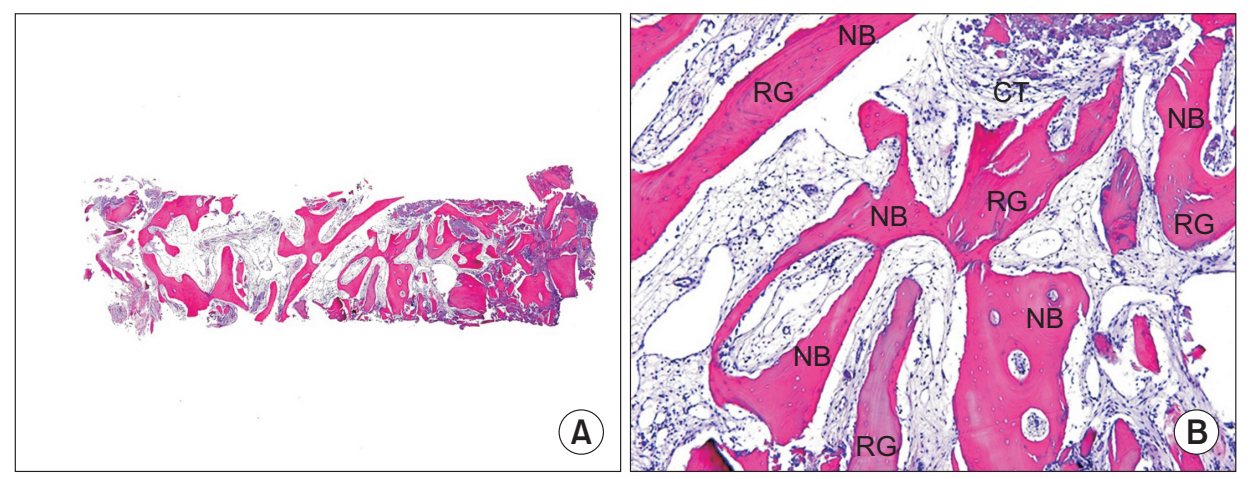

Fig. 9. Histologic view and histomorphometric analysis of case 3 (H\&E stained, A: $\times 40, \mathrm{~B}: \times 100)$. (A) Although some grafted bone grafts are combined with each other due to the deposition of new bone around them, the resorption of some grafts and the surrounding fibrous connective tissue was observed in the area where the grafts were densely distributed. (B) The sample shows $20.1 \%$ NB, $16.1 \%$ RG, and $63.8 \%$ CT. NB, newly formed bone; RG, residual bone graft; CT, connective tissue.

kinase) 세포 표면 수용체에 결합하여 신호 전달 경로를 시작하 게 한다. 궁극적으로 세포 내 단백질은 여러 조절 복합체를 형성 하여 유전자 발현을 촉진하고 핵에서 표적 유전자의 프로모터 (promoter) 영역에 결합한다.

BMP-2를 포함한 BMP들은 골모세포 형성과 신생골 형성에 영향을 미치는 몇 가지 중요한 경로에 관여한다: Smad 경로, Hedgehog 경로, TGF- $\beta$ 경로 및 사이토카인-사이토카인 수용 체 상호작용. BMP-2 표적 유전자는 세포핵에 위치한 광범위한 전사 인자 코호트를 포함한다. BMP2의 골재생 효과는 Runx2Smad 복합체의 형성에 의해 매개된다[5]. TGF- $\beta$ 세포 내 단백 질인 Smads는 전사 인자와 조절 복합체를 형성하여 세포 내 신 호전달의 표현형 표적 유전자 유도를 조절한다. BMP-2는 세포 핵에서 일련의 전사인자(RUNX2, OSX, DLX5)의 발현을 증가 시켜 조골세포 성숙을 촉진하고, 이는 조골세포 표시 유전자인 OSE2의 발현을 유도한다[6].

$\mathrm{BMP}$ 는 골과 연골의 형성을 유도하는 능력을 가진 단백질로 알려져 있는데 Urist 등[7]이 탈회처리한 골을 골조직이 없는 조 직에 매식하여 거기에서 새롭게 신생골을 형성할 수 있음을 증 명했다. 이 실험을 통해 처음 탈회된 골기질에서 골 유도 능력이 있는 단백질이 있음을 밝히고 BMP라 명명하였다[7]. 이후 1988 년에 Wang 등[8]에 의해 $\mathrm{cDNA}$ 복제에 성공하여 $\mathrm{BMP}$ 의 전 염 기서열이 밝혀졌고 현재에는 20종류 이상이 확인되었다.

임상에서 사용 가능한 BMP는 2종류로 정제된 BMP와 재조 합 BMP가 있는데 정제된 $\mathrm{BMP}$ 는 복잡한 정제 방식과 채취량 이 적고 단독 사용시 바로 대사되는 단점이 있다[9,10]. 현재는 재조합 유전자 기술의 발달로 골유도 능력을 갖고 있는 다양한 recombinant human BMP를 생산할 수 있게 되었다[11,12].

$\mathrm{BMP}$ 중에서 BMP-2와 BMP-7이 가장 활성이 뛰어난 것으로 여겨지는데 특히 구강악안면 영역에서 많은 BMP-2 임상실험이
보고되었다. Han 등[13]은 BMP-2와 BMP-7은 bone remodeling 동안 골과 연골의 성장 및 항상성 유지에 유의미한 효과 가 있다고 하였고 Yasko 등[14]은 rhBMP-2가 mesenchymal stem cells로부터 골아세포의 증식을 촉진시키면서 골기질의 생 합성을 활성화 시킨다고 하였다.

Boyne 등[15]은 상악동저골이식술에서 rhBMP-2의 안전성 과 효과에 대한 연구를 하였는데 $\mathrm{CBCT}$ 분석에서 모든 환자에 있어 평균 $8.51 \mathrm{~mm}$ 높이의 유의한 골 성장이 관찰되었고 임플 란트 식립 시 채취한 core bone에 대한 조직검사에서 양질의 신생골을 확인하였다. Triplett 등[16]은 상악동저골이식술에 서 rhBMP-2를 적신 콜라겐 스펀지만을 넣고 이를 자가골을 이 식한 경우와 비교 실험과 결과 골형성 속도의 차이는 없었으나 $\mathrm{rhBMP}-2$ 를 적용한 그룹에서 자가골에 비해 더 높은 골밀도를 가진 신생골이 만들어진다고 보고하였다. Gutwald 등[17] 역시 상악동거상술 후 $\mathrm{rhBMP}-2$ 를 적신 콜라겐만 넣거나 자가골을 이식한 뒤 각기 다른 제조사의 임플란트를 식립하여 bone-toimplant contct (BIC), 골밀도(bone density)를 비교 실험한 결 과 두 그룹간 골형성 속도 차이는 없으나 콜라겐만을 넣은 실험 군이 대조군보다 유의할 정도의 높은 BIC와 골밀도를 보였다고 하였다.

$\mathrm{BMP}$ 는 수용성이고 단독으로 사용시 즉시 분해되어 골유도 효과를 거의 볼 수 없다[18]. 따라서 운반체 역할을 할 수 있는 scaffold가 반드시 필요한데 이 scaffold는 BMP 방출량을 조절 하면서 BMP의 파괴나 비활성화에 대해 보호할 수 있어야 하고 생체적합성이나 예측할 수 있는 생체분해성, 적절한 염증반응 유도능력과 같은 일반적인 요구조건을 충족시켜야 이상적이다 [19,20]. Scaffold로 사용되고 있는 여러 가지 재료 중 현재 임상 에서 가장 널리 사용되고 있는 것은 collagen과 TCP이다[21]. Herford [22]는 rhBMP-2를 자가골이나 이종골에 섞어 쓰는 경 
우 골광화가 더 빠르게 진행되어 임플란트 식립 시기를 앞당길 수 있다고 하였고 Schwartz 등[23]은 deproteinized cancellous bovine bone을 운반체로 이용 시 운반체로서의 역할과 동 시에 골유도 효과가 있다고 밝혔다. Jung 등[24]은 HA를 scaffold로 사용하여 연구를 진행하였는데 골유도재생술에 이종골 과 rhBMP-2를 함께 적용한 경우 rhBMP-2를 적용하지 않은 군 에 비해 신생골 형성에 유의한 차이가 있다고 보고하였고, Ahn 등[25]은 rhBMP-2가 우수한 골유도성 치유능력을 지니고 있으 며 anorganic bovine bone 자체가 골이식재로서의 역할을 수 행하면서 동시에 rhBMP-2 운반을 위한 효과적인 scaffold로 유 용하게 사용될 수 있다고 보고하였다.

최근 고찰 논문들의 결과들을 살펴보면, 상악동저골이식술에 rhBMP-2를 사용한 경우 기존의 수술방법과 비교하여 치유 기 간 6-9개월 후 골형성량의 수치 및 조직학적 결과에서의 유의 한 차이를 보이지 않는 것으로 나타났다. 유사한 결과가 이전에 de Freitas 등[26]에 의해 출판된 체계적인 고찰 논문에서도 보 고되었다. 다른 체계적 고찰 논문에서는 자가골 이식 후 상악저 골이식술이 수직골 증가 측면에서 rhBMP-2/ACS 그룹보다 유 의하게 더 크다고 보고했다[27]. 이 고찰 논문에는 더 많은 무작 위 대조 시험이 포함되었고, 신생골형성과 잔여골이식재의 비 율에 대해서는 유의한 차이가 발견되지 않았다. 이는 상악동저 골이식술에서 $\mathrm{rhBMP}-2$ 가 기존의 골이식술과 유사한 조직학 적 결과를 얻었다는 것을 의미한다. 그러나 이러한 결과는 단 지 3개의 연구[28-30]와 6-9개월의 추적 관찰에 기초한 것이라 는 점은 주목할 필요가 있다. 이 세 가지 연구 중 한 연구에서는 비탈회해면골[29], 다른 연구에서는 이종골이식재[28], $\beta$-TCP [30]를 rhBMP-2의 운반체로 사용했다. 또한 메타 분석에서 신 생골형성 비율에서 유의미한 차이를 발견하지 못했지만 Kao 등 [28]의 연구에서는 단백질이 제거된 소뽸를 운반체로 사용했을 때 신생골형성이 더 적게 일어났다고 보고했다.

이 연구에서는 cancellous FDBA와 cortical FDBA가 3:7인 비율의 mixed FDBA를 scaffold로 사용하였는데 다른 연구들 [5-7]의 신생골 형성비율(16.04\%-24.1\%)보다 더 높은 비율의 신생골 형성량을 나타내었고, 이는 cancellous FDBA와 cortical FDBA의 혼합 FDBA가 rhBMP-2와 같이 사용되었을 때 임 플란트를 식립하기에 충분한 신생골을 형성할 수 있고 이러한 결과로 좋은 임플란트 초기 고정력을 보였다. 따라서 상악동저 골이식술의 연구에서 rhBMP-2와 mixed FDBA와 함께 사용한 더 많은 증례들에서 임상적, 조직학적 분석을 시행할 필요가 있 다고 생각된다.

\section{Acknowledgements}

This study was supported by research funds from Chosun Dental Hospital, 2019.

\section{Conflicts of Interest}

The authors declare that they have no competing interests.

\section{ORCID}

\author{
Ock-Hyun Cho \\ https://orcid.org/0000-0001-7879-2632 \\ Won-Pyo Lee \\ https://orcid.org/0000-0003-1911-3454 \\ Sang-Joun Yu \\ https://orcid.org/0000-0001-8818-549X
}

\section{References}

1. Kim YK. Bone graft using two types of scaffolds and recombinant human bone morphogenetic protein-2: case series study. Oral Biol Res 2014;38:127-134. doi: 10.21851/ obr.38.2.201410.127.

2. Han MW, Lee JK. Clinical study on the efficacy of the autogenous tooth bone graft material (AutoBT). J Korean Assoc Maxillofac Plast Reconstr Surg 2013;35:221-226. doi: 10.14402/jkamprs.2013.35.4.221.

3. Hwang ST, Han IH, Huh JB, Kang JK, Ryu JJ. Review of the developmental trend of implant surface modification using organic biomaterials. J Korean Acad Prosthodont 2011;49:254-262. doi: 10.4047/jkap.2011.49.3.254.

4. Cheng H, Jiang W, Phillips FM, Haydon RC, Peng Y, Zhou L, Luu HH, An N, Breyer B, Vanichakarn P, Szatkowski JP, Park JY, He TC. Osteogenic activity of the fourteen types of human bone morphogenetic proteins (BMPs). J Bone Joint Surg Am 2003;85:1544-1552. doi:10.2106/00004623200308000-00017. Erratum in: J Bone Joint Surg Am 2004;86-A:141.

5. Hassan MQ, Tare RS, Lee SH, Mandeville M, Morasso MI, Javed A, van Wijnen AJ, Stein JL, Stein GS, Lian JB. BMP2 commitment to the osteogenic lineage involves activation of Runx2 by DLX3 and a homeodomain transcriptional network. J Biol Chem 2006;281:40515-40526. doi: 10.1074/jbc.M604508200.

6. Komori T, Yagi H, Nomura S, Yamaguchi A, Sasaki K, Deguchi K, Shimizu Y, Bronson RT, Gao YH, Inada M, Sato M, Okamoto R, Kitamura Y, Yoshiki S, Kishimoto T. Targeted 
disruption of Cbfa1 results in a complete lack of bone formation owing to maturational arrest of osteoblasts. Cell 1997;89:755-764. doi: 10.1016/s0092-8674(00)80258-5.

7. Urist MR. Bone: formation by autoinduction. Science 1965;150:893-899. doi: 10.1126/science.150.3698.893.

8. Wang EA, Rosen V, Cordes P, Hewick RM, Kriz MJ, Luxenberg DP, Sibley BS, Wozney JM. Purification and characterization of other distinct bone-inducing factors. Proc Natl Acad Sci U S A 1988;85:9484-9488. doi: 10.1073/ pnas.85.24.9484.

9. Urist MR, Dowell TA, Hay PH, Strates BS. Inductive substrates for bone formation. Clin Orthop Relat Res 1968;59:59-96. doi: 10.1097/00003086-19680700000005.

10. Yeomans JD, Urist MR. Bone induction by decalcified dentine implanted into oral, osseous and muscle tissues. Arch Oral Biol 1967;12:999-1008. doi: 10.1016/00039969(67)90095-7.

11. Kim SJ, Kim MR, Oh JS, Han I, Shin SW. Effects of polycaprolactone-tricalcium phosphate, recombinant human bone morphogenetic protein-2 and dog mesenchymal stem cells on bone formation: pilot study in dogs. Yonsei Med J 2009;50:825-831. doi: 10.3349/ymj.2009.50.6.825.

12. Lee JH, Kim CS, Choi KH, Jung UW, Yun JH, Choi SH, Cho KS. The induction of bone formation in rat calvarial defects and subcutaneous tissues by recombinant human BMP-2, produced in Escherichia coli. Biomaterials 2010;31:35123519. doi: 10.1016/j.biomaterials.2010.01.075.

13. Han DK, Kim CS, Jung UW, Chai JK, Choi SH, Kim CK, Cho KS. Effect of a fibrin-fibronectin sealing system as a carrier for recombinant human bone morphogenetic protein- 4 on bone formation in rat calvarial defects. J Periodontol 2005;76:2216-2222. doi: 10.1902/jop.2005.76.12.2216.

14. Yasko AW, Lane JM, Fellinger EJ, Rosen V, Wozney JM, Wang EA. The healing of segmental bone defects, induced by recombinant human bone morphogenetic protein (rhBMP-2). A radiographic, histological, and biomechanical study in rats. J Bone Joint Surg Am 1992;74:659-670. Erratum in: J Bone Joint Surg Am 1992;74:1111.

15. Boyne PJ, Marx RE, Nevins M, Triplett G, Lazaro E, Lilly LC, Alder M, Nummikoski P. A feasibility study evaluating rhBMP-2/absorbable collagen sponge for maxillary sinus floor augmentation. Int J Periodontics Restorative Dent 1997;17:11-25.

16. Triplett RG, Nevins M, Marx RE, Spagnoli DB, Oates TW, Moy PK, Boyne PJ. Pivotal, randomized, parallel evaluation of recombinant human bone morphogenetic protein-2/ absorbable collagen sponge and autogenous bone graft for maxillary sinus floor augmentation. J Oral Maxillofac Surg 2009;67:1947-1960. doi: 10.1016/j.joms.2009.04.085.

17. Gutwald R, Haberstroh J, Stricker A, Rüther E, Otto F, Xavier SP, Oshima T, Marukawa E, Seto I, Enomoto S, Hoogendijk CF, Schmelzeisen R, Sauerbier S. Influence of
rhBMP-2 on bone formation and osseointegration in different implant systems after sinus-floor elevation. An in vivo study on sheep. J Craniomaxillofac Surg 2010;38:571-579. doi: 10.1016/j.jcms.2010.02.010.

18. Sato K, Urist MR. Induced regeneration of calvaria by bone morphogenetic protein (BMP) in dogs. Clin Orthop Relat Res 1985;(197):301-311.

19. Karfeld-Sulzer LS, Weber FE. Biomaterial development for oral and maxillofacial bone regeneration. J Korean Assoc Oral Maxillofac Surg 2012;38:264-270. doi: 10.5125/jkaoms.2012.38.5.264.

20. Haidar ZS, Hamdy RC, Tabrizian M. Delivery of recombinant bone morphogenetic proteins for bone regeneration and repair. Part A: current challenges in BMP delivery. Biotechnol Lett 2009;31:1817-1824. doi: 10.1007/s10529009-0099-x.

21. Urist MR. Experimental delivery systems for bone morphogenetic protein. In: Wise DL, Altobelli DE, Schwartz ER, Gresser JD, Trantolo DJ, Yaszemski M, editors. Handbook of biomaterials and applications, section 3: orthopaedic biomaterials applications. Boston: Marcel Dekker; 1995. p. 1093-1133.

22. Herford AS. rhBMP-2 as an option for reconstructing mandibular continuity defects. J Oral Maxillofac Surg 2009;67:2679-2684. doi: 10.1016/j.joms.2009.07.096.

23. Schwartz Z, Weesner T, van Dijk S, Cochran DL, Mellonig JT, Lohmann CH, Carnes DL, Goldstein M, Dean DD, Boyan BD. Ability of deproteinized cancellous bovine bone to induce new bone formation. J Periodontol 2000;71:12581269. doi: 10.1902/jop.2000.71.8.1258.

24. Jung RE, Glauser R, Schärer P, Hämmerle CH, Sailer HF, Weber FE. Effect of rhBMP-2 on guided bone regeneration in humans. Clin Oral Implants Res 2003;14:556-568. doi: 10.1034/j.1600-0501.2003.00921.x.

25. Ahn KJ, Park JC, Kim YK. Experimental study on healing procedure after combined grafting of recombinant human bone morphogenetic protein-2 and anorganic bovine bone. Oral Biol Res 2014;38:83-91. doi: 10.21851/ obr.38.2.201410.83.

26. Freitas RM, Spin-Neto R, Marcantonio Junior E, Pereira LA, Wikesjö UM, Susin C. Alveolar ridge and maxillary sinus augmentation using rhBMP-2: a systematic review. Clin Implant Dent Relat Res 2015;17 Suppl 1:e192-e201. doi: 10.1111/cid.12156.

27. Lin GH, Lim G, Chan HL, Giannobile WV, Wang HL. Recombinant human bone morphogenetic protein 2 outcomes for maxillary sinus floor augmentation: a systematic review and meta-analysis. Clin Oral Implants Res 2016;27:1349-1359. doi: 10.1111/clr.12737.

28. Kao DW, Kubota A, Nevins M, Fiorellini JP. The negative effect of combining rhBMP-2 and Bio-Oss on bone formation for maxillary sinus augmentation. Int J Periodontics Restorative Dent 2012;32:61-67. 
29. Froum SJ, Wallace S, Cho SC, Khouly I, Rosenberg E, Corby P, Froum S, Bromage T, Schoor R, Norman R, Tarnow DP. Histomorphometric comparison of different concentrations of recombinant human bone morphogenetic protein with allogeneic bone compared to the use of $100 \%$ mineralized cancellous bone allograft in maxillary sinus grafting. Int J Periodontics Restorative Dent 2013;33:721-730. doi: 10.11607/prd.1736.

30. Kim MS, Lee JS, Shin HK, Kim JS, Yun JH, Cho KS. Prospective randomized, controlled trial of sinus grafting using Escherichia-coli-produced rhBMP-2 with a biphasic calcium phosphate carrier compared to deproteinized bovine bone. Clin Oral Implants Res 2015;26:1361-1368. doi: 10.1111/clr.12471. 